\title{
Geographical Connections: Law, Islands, and Remoteness
}

\author{
Matteo Nicolini ${ }^{1,2,3,4}\left(\right.$ C) Thomas Perrin $^{5}[$
}

Published online: 15 October 2020

(c) Springer Nature B.V. 2020

\begin{abstract}
The paper introduces a special issue dedicated to cross-disciplinary research on insular condition and insularity. Situated at the crossroads of legal and geographical studies, it explores the intriguing topic of "Island-ness" by placing emphasis on how physical, legal, and imaginative remoteness articulates a variety of geographical connections. These reflect several issues, such as territorial (and maritime) localisation, insular ontology, colonial and post-colonial imaginaries. The special issue delivers both a synthetic view of these questions and opens up further perspectives for reflection. The papers examine how geographical connections trigger different legal, as well as constitutional, frameworks suitable for geographically distant islands, which, evidently, depend on how remote these islands actually are. The contributions survey various topics and adopt different approaches in order to ascertain how geographical connections and remoteness intertwine. Beyond this richness of inputs, the essays reveal some common features of islands and remoteness as objects of geographical and legal representation. Besides organising society, the law arranges geographical connections so as to act as a bridge linking the reality of remoteness to an imagined alternative able of securing the governance of the abovementioned remote societal contexts.
\end{abstract}

Keywords Island · Remoteness · Interdisciplinarity research · Isolation · EU cohesion policies · Greek archipelagos $\cdot$ British overseas territories · American territories

\footnotetext{
This article and the special issue pertain to the activities of the IEL (innovative education laboratory) GEOLawB, which is part of the research excellence project "Law, Changes and Technology"Ministry of Education and carried out by the Law School of the University of Verona.
}

Matteo Nicolini

matteo.nicolini@univr.it

Extended author information available on the last page of the article 


\section{Cross-Disciplinary Connections: Locating Insular Remoteness in Legal Geographical Investigations}

The special issue "Geographical connections: Law, Islands, and Remoteness" introduces a cross-disciplinary research which both editors have been conducting for the last two years. The research explores the intersections that insular remoteness exhibits in several ambits, such as legal and geographic studies, political power, fiction, and literature. Like the tiles of the roofs, these ambits reflect islands' territorial localisation, as well as the insular societal contexts in which they are imbricated.

The special issue, which addresses the intriguing topic of 'Island-ness,' is situated at the crossroads of legal and geographical studies. As we shall see in due course, the law interweaves with physical, legal, and imaginative remoteness, and triggers a variety of geographical connections. This reflects several topics and manifold geographical concerns; among the others, territorial (and maritime) localisation, insular connectivity and ontology, the impact of environmental crises on insular remoteness, and the effects of colonial legacies on post-colonial insular imaginaries.

Remoteness, in general, and insular remoteness, in particular, represents "a complex idea placed at the core of geographic interest". ${ }^{1}$ In geographical research, the topic is well-charted and widely explored. The descriptor is linked, for example, to the concept of continentality, which "describes how the climate of a place is affected by its remoteness from the oceans." 2 Together with remoteness, concepts such as 'isolation' and 'distance' also display vivid geographical connotations: "Depending on the distance to a coastline and on its connectivity," islands or archipelagos "may be remote in several respects: by being at an edge, being far, being ill-connected or by a combination of those." 3

This assumption is apparent when navigating toward the South Atlantic Ocean, where the British Empire established an oceanic path consisting in "a cascade of islands," and in "chains of islands and reefs." 4 Such cascade provides us with a set of geographical connections. It is the case of the constellation of British Overseas Territories (BOTs), it stretches from Saint Helena, to Tristan da Cunha, and Ascension; the latter is also the "essential staging post for flighting to and from the Falkland Islands" and its former dependencies. ${ }^{5}$

There are further varieties of cascades of islands. This phenomenon was first grasped by the literary genre of Isolario, or "book of the islands", which developed from the fifteenth to the seventeenth centuries at the Age of Discovery. As a literarygeographical genre, it proposed a novel system for representing the maritime space beyond the continental shores as it had been previously depicted on portolan charts.

\footnotetext{
1 On remoteness in geographical studies see Bocco (2016) 178. On small and remote islands in geographic studies see e.g. Royle (2011).

2 Allaby (2020): 140.

3 Bocco (2016) 179. See also Royle (2011): 110.

4 See, respectively, Bottomley (2020): 254 and Mentz (2015): 52.

5 See Lovegrove (2012): 68 (Ascension), 104 (Tristan da Cunha), and 136 (Georgia); see also Fichter (2008).
} 
The Isolario embodies a new maritime cosmographic narrative, an eclectic encyclopaedia of mapped islands in the form of insular constellation. It "flourished in the Mediterranean region (the main centers were Florence and Venice) [...], covering a wide range of learned, practical, and informational needs". 6

The Isolario is the forerunner of cross-disciplinary representations of geographical patterns, inasmuch as it "belongs somewhere within the shadowy bounds of geographical, historical, and travel literature and nautical manuals." In addition, it witnesses "the inherent fluidity of the discipline of geography" and its ambition of engaging in dialogues with other disciplines, such as legal studies. ${ }^{7}$

Cross-disciplinary ambitions usually go above and beyond the representations of insular patterns. This is apparent as far as insular remoteness is concerned. Its literary implications need not detain us here; suffice it to remember that examples of the metaphorical use of the island have traditionally fascinated lawyers, poets, pamphleteers, and novelists. ${ }^{8}$ There is, for example, the narrative of the legendary "Fortunate Isles," or "Islands of the Blest" located in the Atlantic, "which has its roots in ancient geography and mythology," attracted the Anglo-British geopolitical imaginaries in the sixteenth century. ${ }^{9}$ But there are also several topical texts; among the others, Shakespeare's The Tempest (1611) More's Utopia (1515), Marvell's Bermuda, De Foe's Robinson Crusoe (1719), Jonathan Swift's Gulliver's Travels (1726), Wells's The Island of Doctor Moreau (1896), Lawrence's The Man Who Loved Islands (1927), Golding's Lord of the Flies (1954), White's A Fringe of Leaves (1977), and Snyder's Orphan Island (2017). Besides the English literary tradition, Umberto Eco, in his outstanding essay about legendary places and lands, illustrated how the insular metaphorical trope is common to many more languages and cultures. ${ }^{10}$

As a specific character of islands, remoteness has therefore displayed (and still displays) true cross-disciplinary ambitions. To this extent, it has triggered geopolitical imagination and nourished a new form of literary and fictional corpus. Like the Renaissance Isolarii, some recent works confirm the particular interest of the "insular questions" because of their interdisciplinary scope and their reflective, fictional, and imaginary potential. As a result, manifold atlases and books portraying the "state of the islands" have been recently published. ${ }^{11}$

\footnotetext{
6 Tolias (2007): 264.

See also the presentation of Isolario in the exhibition "L'Âge d'or des cartes marines", Bibliothèque nationale de France, online: https://expositions.bnf.fr/marine/arret/09-4.htm (Accessed on 7 September 2020).

7 Tolias (2007): 263.

${ }^{8}$ Lovegrove (2012): 3 . On the literary intertwining of islands and remoteness see the essays collected in Nicolini and Perrin (2020).

9 Waters Bennet (1956): 114

${ }^{10}$ Eco (2013).

11 To quote just a few, Schalansky (2010); Lovegrove (2012); McMahon (2016); Smith (2017); Berthet (2020). See also the several books of the "Rethinking the Island" series edited by Elaine Stratford, Godfrey Baldacchino and Elizabeth McMahon at Rowman \& Littlefield publishers, and the proceedings of the international academic and cultural event of October 2019, Îles 2019: regards croisés des sciences, des cultures et de la société, https://iles2019.sciencesconf.org (accessed on 31 August 2020). For an updated bibliography, see Le Monde (2019); and the catalogue of the exhibition Le Temps de l'île, from
} 


\section{"Surrounded by Wild Waters": Establishing Insular Connections in Law and Geography}

Scattered across the oceans, islands display an intriguing spatial articulation, which is even more intriguing when situated in higher latitudes: "surrounded by wild waters, cliff-bounds islands appear formidably awesome as well as starkly beautiful." 12

As a form of insular sublime, remoteness reinforces our cross-disciplinary commitment to join lawyers, geographers, and literary scholars in navigating open water and exploring far-off islands. Conceiving of, experimenting, and deploying innovative cross-disciplinary methodologies will shed new light on the politico-legal and cultural implications of the relation between law and geography.

Insular "remoteness" assumes several connotations. The term is indeed a composite of three distinct, albeit interlocked, forms of remoteness: the physical, the imaginative, and the politico legal. Physically, islands are remote because they are geographically distant, isolated, and inaccessible. Owing to their boundaries, which "are narrow and firmly defined," 13 remote islands have become the metaphor of the Anthropocene, which places emphasis on their "relative, geographic dimension, subject to scale, and to connectivity rather than distance."14

Isolation and remoteness are therefore relative 'spatialities.' In Islands Beyond the Horizon, for example, Roger Lovergrove juxtaposes the Tuamotu Archipelago in Oceania to St Kilda, i.e. the westernmost islands of the Outer Hebrides of Scotland. Whereas the former is made less isolated and "out of touch" by "modern satellite communications," "naturalists and travellers have made repeatedly unsuccessful attempt to land" on St Kilda "even in the summer season," which obviously "concur in its inaccessibility." 15

Likewise, the law may trigger forms of insular remoteness. As Boumpa and Paralikas put it in The Greek Archipelago: A unique representative case-study of differential legal status and of double insularity, the Greek statute No. 4551/2018 (on the implementation, monitoring and general conditions of transport among Greeks islands) has triggered a plurality of insular connections and, at the same time, remoteness and isolation. Firstly, there is the phenomenon that the authors label "double insularity": "Smaller islands, isolated and remote ones are connected to larger ones in matters of public health care, education and appeal in courts as well as in matters of various administrative issues." There are also islands that are excluded by the scope of the law: "The first two islands are Lefkada and Evia, which are close enough located to the mainland;" and bridges connect them to the mainland. There

\footnotetext{
Footnote 11 (continued)

17 July 2019 to 20 November 2019, Mucem Marseilles (https://www.mucem.org/media/5591 (accessed on 31 August 2020).

12 Lovegrove (2012): 3.

13 Lovegrove (2012): 3.

14 Bocco (2016): 178. On islands as metaphors of the Anthropocene see Pugh (2018); Chandler and Pugh (2020).

15 Lovegrove (2012): 1-2.
} 
is also Crete; being, as it is, the biggest island of Greece, it is a per se administrative prefecture. Finally, islands also populate the Greek lakes, thus "contributing to the formation of a sui generis socio-economic," insular, and "legal area". 16

But relative, i.e. imaginative, insular remoteness has relational implications which point to how these islands have traditionally been represented, say, by colonial powers. Within the legal geography of the BOTs, for instance, remoteness defines faraway "tracts of country", where "settlement" was often "impracticable."17 As Michael Bromby argues in The Cayman Islands: Paradoxes of Insularity in the Caribbean and other British Overseas Territories, many BOTs are geographically remote. However, they share manifold forms of connectivity: besides displaying chains and cascades of islands, the BOTs are still being networked through a variety of geographical connections. Indeed, the British Empire "created a number of "corridors':" and "persons, trade and power travelled in various directions to and from the United Kingdom, principally London, as the legal centre of the empire."18 Evidently, corridors were aimed at linking "the most distant and isolated colonies in a hub and spoke model, occasionally with clusters connecting discrete geographical areas together such as the British West Indies." 19

No wonder, therefore, if the Empire, which Great Britain had fashioned as a "well-earn'd empire of the deep", ${ }^{20}$ displayed several forms of connectivity. Which, evidently, provides scholars with several and enthralling possibilities of cross-cutting reflections in the fields, even the remotest ones, of law and geography.

\section{Managing Geographical Connections: How Remoteness Works}

Not only are remote islands geographical subjects par excellence, but they also lie at the crossroads of several areas, namely law, geography (whether it be physical, political, imaginative), literature, planning, politics, art, and cultural studies.

This special issue on "Geographical Connections: Law, Islands, and Remoteness" intends to provide the reader with several applications of how remoteness works. As already noticed, this might be imaginative, i.e., isolated and protected from the 'real' world and, at the same time, connected to it by a shifting web of relations. To this extent, islands have traditionally resonated with colonialism, in general, and their social and cultural imaginaries, in particular. The Imperial corridors we mentioned above created a web of relations between geographically remote islands; by virtue of conquest and settlement, the legal system of the motherland was extended to these remote tracts of lands; in several cases, conquest entailed the translation of the idea of "garden-paradise" from the motherland into the tropics. In a recent essay, Anne Bottomley has demonstrated how this geographical imaginative connection worked

\footnotetext{
16 Boumpa and Paralikas (2021): 32.

17 Roberts-Wray (1966): 543.

18 Bromby (2021). On the governance of the BOTs see Hendry and Dickson (2018).

19 Bromby (2021). See also Hilary McD. Beckles (1999).

20 Thomson (1802): line 166.
} 
in the case of Bermuda. ${ }^{21}$ It is not surprising, therefore, that the island, which had been originally named Devils Island, had its name changed into Sommers Island in 1615, i.e. after the colony was founded in 1612 by Sir George Sommers. Not only is Bermuda the metaphor of the Eden, but the same ocean is a "wat'ry maze" which bridges English religious-legal reality to its imagined and insular alternative.

This shifting web of relations is boosted by globalisation; and geographical insular demarcation provides the law with incredible possibilities of experimentation. Together with global commercial law and its "aesthetic consequences [...] including [its] sublime effects," ${ }^{22}$ markets advocate for homogeneous politico-legal features throughout the world. In an economic-oriented environment, such a universalist approach manages complexity by simplifying it. Consequently, islands act as geographical discontinuities disturbing the allegedly universalising effects of globalisation. ${ }^{23}$ And the current globalisation of flows - including the information and financial flows-reinforces this permanent dialectic between geophysical discontinuity and mainland connection.

Such geographical connections might also be paradoxical, as in the case of Guam, which, according to Colin Jones's The Islands that Ate the Constitution, is one of the many great mysteries about the legal status of this U.S.'s insular territory. Jones's essay revolves around the following point: "The US constitution becomes a different document if, while reading it, each time you see the word 'state,' you ask the question: 'what if you aren't a state, or in one?'”. There are-Jones argues-several answers to this question, which demonstrate "how different the constitution can be, depending upon where in 'America' you actually are." In the case of Guam and the U.S. territories, remoteness should be intended as distance from Washington and the political power. The cascade of U.S. islands turns out to be a "scattering of disparate island territories:" Guam, the Commonwealth of the Northern Mariana Islands (CNMI), American Samoa in the Pacific, the U.S. Virgin Islands, and Puerto Rico "offer a panoply of additional exceptions and divergences from what would seem to be well-established constitutional that can be clearly derived from the black letter of the Constitution." 24

Remoteness might also raise substantive issues, when, for instance, it comes to distinguishing islands from rocks, and to legally defining the former. Scholars may contribute to the process of producing new geographical, social, and legal taxonomies and terminology, in relation to islands. Sondra Faccio's "Human Habitation or Economic Life of their Own." The definition of an island between history, technology and the law of international law the island represents as a piece of land surrounded by waters, which can be the stage of some human activity. The definition of what an "island" is under international law is set in article 121(3) of the United Nations Convention on the Law of the Sea (UNCLOS). This provision distinguishes islands from rocks and defines the former as naturally formed areas of land, surrounded by water

\footnotetext{
21 See Bottomley (2020).

22 Hugues (2007): 696.

23 According to Monateri (2018): 135, islands are "fractures" of the global space.

24 Jones (2021).
} 
that are above water at high tide. Rocks, by contrast, are features, "which cannot sustain human habitation or economic life of their own." We understand that there might be something beneficial in turning a feature into an island; in so doing, Sondra Faccio acutely argues, States expand their sovereign rights by expanding their exclusive economic zone (EEZ) and, at the same time, reduce the extent of the International Seabed Area as the common heritage of mankind. Whereas several coastal States have used their quasi-insular features to broaden their own EEZ, China "has turned seven reefs in the Spratlys into artificial islands;" it has then "occupied the islands it built, erected structures, paved runways, and installed military defenses." 25 It is a "veritable process of 'islandization' ... in the attempt to satisfy the requisites established by article 121(3) of UNCLOS." 26

Islands and its variants-like "insularity" or "insular" - may also be found in domestic law and in EU law, where they define the statuses of insular entities. We can mention Arts. 72-3 and 72-4 of the French Constitution; in EU law, the expression « régions insulaires» in the French version of Art. 170(2) TFEU is usually translated with "island regions" into English. Danielle Perrot precisely explores how remoteness intertwines with the legal statuses of islands in her essay Insularity and Law: Diversity and Changeability of Islands' Statuses. The Example of French Outermost Regions in French and EU Law Systems. Again, Boumpa and Paralikas consider modes of legal discourse when it comes to the Greek Archipelago, where insularity affects and shapes the adoption, as well as the implementation, of laws. And Bromby considers how the constitutional legal regimes of the Cayman Islands respectively depend on how the United Kingdom has set them at the crossroads of many connections to other parts of the world that are geographical, legal and socio-political.

In their Rural Development and the "POSEI" Regime for European Islands: Between Remoteness, Subsidiarity and the "Delivery Model”, Luchino Ferrari and Gianluca Frinzi explain why insularity and remoteness are key concerns of the EU agricultural policy. The geographical connection turns out to be a form of socioeconomic connectivity: islands have specific features and constraints, which, for example, entail additional costs in transporting products from/to the islands. Within the EU, they are dependent upon a targeted assistance by the EU legislator. Consequently, the EU provides them with an invaluable support, particularly through its rural development policy and in its dedicated "Programme of Options Specifically Relating to Remoteness and Insularity" ("POSEI") aet forth by the EU Regulation No 228/2013. ${ }^{27}$

\footnotetext{
25 Gaynor (2020): 109.

26 Faccio (2021)

27 Ferrari and Frinzi (2021).
} 


\section{The geographical connection again: location, area, and environment}

As is evident, the legal-geographical approach to islands adopted in this special issue points out a certain apparent paradox, between isolation and linkage, which turns out to be a dialectic. At the same time, and beyond this richness of inputs, the essays reveal some common features: islands and remoteness as objects of geographical and legal representation. From the geophysical point of view, islands are isolated and disconnected from mainland by water. Besides organising society, the law arranges geographical connections so as to act as a bridge linking the reality of remoteness to an imagined alternative able of securing the governance of the abovementioned remote societal contexts. During the course of human history, indeed, it has progressively related the vast majority of islands and islanders to continental or "metropole" legal, political, cultural, and economic systems, be it by conquest, colonisation, or by the progressive globalisation of flows of people, goods, capital, and information.

Even sovereign insular states could not—and cannot—develop without a relation to other continental or mainland states and societies.

As a result of this isolation-connexion dialectic, many countries, most of them continental, include within their national borders insular territories, distributed all over the Earth surface. Even a novel and hybrid socio-political ensemble like the European Union recognises within its territorial realm outermost regions and overseas countries and territories, many of which are islands. ${ }^{28}$ The Islands commission of the Conference of peripheral maritime regions of Europe represents the interests of more than 20 European regional island authorities located in the Mediterranean, North Sea, Baltic Sea and the Atlantic, Indian and Pacific Oceans, many of which pertain to EU member States like Denmark, France, Portugal, Spain, among the others.

As Danielle Perrot reminds us, the history of European integration is also a struggle for insular recognition: the currently seven European Overseas Regions (ORs) the four French regions, the Canary Islands, the Azores and Madeira-progressively gained the recognition of their distinctive characteristics with the approval of the Maastricht and Amsterdam Treaties. ${ }^{29}$ Their "structural, social and economic situation" must be taken into account since they are compatible with the internal market (Art. 107.3.a TFEU). Due to these situations, measures may be adopted in order to sustain the ORs, without "undermining the integrity and the coherence of the [EC/ UE] legal order" (Art. 349 TFEU). Finally, Treaty of Lisbon now allows EU ORs to change their status under the EU law (Art. 355.6 TFEU); and Danielle Perrot explains how this has affected French overseas entities. ${ }^{30}$

The geographical conditions of islands also entail an environmental dialectic, between the preserved and the threatened island. Isolation has provided remarkable

\footnotetext{
28 Articles 349 and 355 of the Treaty on the Functioning of the European Union (TFEU). See Kochenov (2011); Athanassiou and Shaelou (2014).

29 Perrot (2021).

30 Perrot (2021).
} 
and often endemic biological parameters to islands, but this uniqueness is accompanied by fragility. Many insular milieus certainly benefit from classified areas, nature reserves or marine parks. Yet the residential attractiveness and lack of available space, in particular on the coastal areas, can lead to land pressure, degradation, and social inequalities. The climatic change dramatically underlines the environmental—as well as social—fragility of islands.

Consequently, a new "geopolitical struggle" has begun. In order "to control the flow of resources," mainly fossil fuel energy, "from and through the north," hence, "capitalist states ... address the problems they have created" to small islands "by deepening" them. ${ }^{31}$ Not only cannot "small island nations" benefit from their tiny EEZ, but, owing to rising sea levels, they also "face the risk of becoming practically uninhabitable," "economically nonviable," and of being "entirely underwater." This has economic consequences that point to both their submersion and the "loss of [their] territory." Certainly, this will affect states' rights to a marine territory under Article 76 of UNCLOS. ${ }^{32}$ We still do not know, however, whether UNCLOS considers the boundaries of EEZs as permanent. To put it another way, it is disputed whether the submersion of islands would unleash their former seabed to pillaging by economic transnational actors, which may try again to convince us of an unceasing economic growth. ${ }^{33}$

This special issue delivers both a synthetic view of these questions and opens up further perspectives for reflection. The contributions engage various topics and adopt different approaches to how geographical connections and remoteness intertwine. Beyond this richness of inputs, the essays reveal some common features of islands and remoteness as objects of geographical and legal representation.

\section{Patterns Of Insular Remoteness. The Structure Of The Special Issue}

The idea of collecting this set of essays on the topic under scrutiny originated with the Call for Papers "Islands and Remoteness in Geography, Law, and Fiction", convened by the editors of the focus: Matteo Nicolini (Law Department, University of Verona, Italy) and Thomas Perrin (UFR de Géographie et d'Aménagement, Université de Lille) on 21-22 November 2019 at Verona University (Verona, Italy). Manifold applicants submitted interesting papers concerning discrete issues related to Island-ness and Insularity.

A first set of papers that encompassed islands in literature and considered them as literary subjects was published in Pólemos in 2020. These mainly focused on islands as markers (and drivers) of identity and as characteristic fictional figures. The issue thus addresses islands by combining their politico-legal and literary-fictional dimensions. ${ }^{34}$

\footnotetext{
31 Mann and Wainwright (2018): 8.

32 Leal-Arcas (2013): 46.

33 Mountz (2015). According to Dasguta et al. (2009), sea level rises will primarily impact islands.

34 Nicolini and Perrin (2020).
} 
As already said, this special issue explores remoteness as a specific character of islands by engaging a dialogue between law and geography. Such a dialogue has triggered geo-political imagination and, through the papers collected in the issue, has confirmed the particular interest of the "insular questions" because of their interdisciplinary scope and their reflective, fictional, and imaginary potential.

The focus begins with Sondra Faccio's “Human Habitation or Economic Life of their Own." The definition of an island between history, technology and the law, where she acutely reappraises the meaning, scope, and potential of Article 121(3) of UNCLOS, which establishes the international-law regime of geographical features. As Sondra Faccio illustrates, the nature of such features impacts on the sovereign rights recognised to the coastal States: like in the above-mentioned case of China's building of island, if the feature is qualified as an island, it entitles the coastal State to 200 miles of (EEZ) and continental shelf, with undisputed right of exclusive exploitation of natural resources located within the area. The international law of the sea generates here insular dialectic between exiguity and vastness. The UN Convention on the Law of the Sea (UNCLOS) outlines "a Sea of Lines and Laws", within which the small-sometimes minuscule - area of some islands can nevertheless provide the owning state with a vast exclusive economic zone (EEZ). ${ }^{35}$ Only recently, however, the intertwining of Island-ness and natural resources exploitation located in the seabed, at relatively reduced costs, has prompted the substantive interpretation of Art. 121(3) of UNCLOS. The award rendered in The South China Sea Arbitration Case (Philippines v. China) in 2016 focused on the interpretation of the wording 'human habitation or economic life of their own.' The connections Faccio seeks are between geographical features (islands and rocks), States' practice, sundry literary sources (logbook, maps, explorer reports, geography books, and so on), and technological developments.

In the second essay (The Cayman Islands: Paradoxes of Insularity in the Caribbean and other British Overseas Territories), Michael Bromby outlines several strands of geographical connections between insular location, colonialism, and the common-law system the Cayman Islands received within the English colonial Empire. As BTO in the Caribbean, Bromby reminds us, there exist many connections to other parts of the world that are geographical, legal and socio-political; yet the Cayman Islands and other such territories exhibit traits that may be described as insular or openly international. Despite this, the Cayman Islands share a heritage with the former British Empire and, for those with a population and operant legal system, the basic underpinning of the English common law. Within his article, Bromby explores how these strands of connections devised of an insular system legal education, and adapted the role judiciary and the jury size to the needs of this minuscule Archipelago.

The patterns of adaptation displayed by Bromby invite us to read Colin Jones's essay (The Island that Ate the Constitution), which reviews and updates the counterintuitive status of non-state territories under the United States constitution. Taking

\footnotetext{
35 Johnson and Braverman (2020): 11. For more on these paradoxical claims on the seabed see Moore (2015): 169-172.
} 
into account the historical interpretation of the "territorial clause" of the U.S. constitution (Art. IV $\S 3 \mathrm{cl} .2$ ), it focuses on insular territories and considers some of the ways in which their island status has affected the direction of this interpretive path. According to the territorial clause, indeed, government does not always have to follow the constitution in U.S. territories that it controls, but may arrange extremely variegated geographical connections with great freedom. As Colin Jones vividly grasps, the Supreme Court's judgements that fall under the umbrella of the Insular Cases "stand for the proposition that the powers of the federal government are presumptively unlimited, so long as they are exercised outside the limited universe of constitutionally-defined 'states'., 36

The special issue then moves from the Anglo-Saxon remote islands to the ORs that have connections with the EU member states. Danielle Perrot's article (Insularity and Law: Diversity and Changeability of Islands' Statuses. The Example of French Outermost Regions in French and EU Law Systems) deals with the interactions between national and European legal corpuses about insular territories. Together with Spanish and Portuguese outermost regions, French overseas territories manage to change EU law in favour of ORs even if the legal differentiation has limits. Moreover, some recent amendments to the French Constitution allow for status variations and even mutations, which can also be found nowadays in EU law.

And this leads us to explore how European islands and other remote territories areas acquire specific features and constraints-and therefore require a targeted assistance at EU level. Luchino Ferraris and Gianluca Frinzi (Rural Development and the "POSEI" Regime for European Islands: Between Remoteness, Subsidiarity and the "Delivery Model") remind us that the EU has put in place numerous provisions that have been providing an invaluable support, particularly through its rural development policy and in its dedicated programme for agriculture in EU outermost regions (POSEI). Currently, discussions for a reform of the EU Common Agricultural Policy (CAP) are ongoing at the EU Parliament and Council. The new system proposed by the Commission legislative proposal (June 2018) supports renovated geographical connections, which are based on the two key concepts of increased subsidiarity and the so-called "delivery model." A crucial question is therefore what the impact of this reform could be, once approved, for agricultural activities in European islands and other remote regions for the future programming period (2021-2027). Ferraris and Frinzi argue that the "delivery model" and subsidiarity complement each other: the new proposed CAP aims at being more subsidiary because, thanks to the result-based approach of the "delivery model," the carrying out of performances at local level will be enhanced. This increased autonomy presents some challenges for insular and remote territories; however, it also presents huge opportunities in terms of political discretion in the choice of the best tools for the management of their own territory, as well as in terms of voice, which means geographical connection, in EU negotiations.

Within the EU, then, Greece's insular space represents a unique case of geographical connection and-as already said-of double insularity in Europe. Anna

36 Jones (2021). 
Boumpa and Apostolos Paralikas (The Greek Archipelago: A unique representative case-study of differential legal status and of double insularity) explain us that, within such insular pattern, smaller islands act as satellites of bigger ones and depend upon them much more than on the mainland. Adoption of laws, public policies, the organization of public administration and the issue of administrative acts take into account this condition. Boumpa and Paralikas examine how the principle of insularity has been enforced by two pieces of legislation: law 4361/2016 on the "Regulation of issues concerning the transfers of soldiers, personnel care and other provisions;" and law 4551/2018 on the "Implementation mechanism, state supervision, general conditions for the implementation of the Transport Equivalent (T.E.).

There is, then, the interdisciplinary connection. By navigating through the essays collected in this special issue, the editors' introduction has sought to demonstrate how islands cannot only be considered from the mere legal, geographic or cultural perspective. Evidently, this special issue does not exhibit this limited approach: its scope is broader and aims to fill a gap in current studies on the topic. As it intends to go above and beyond the traditional perspective, it explores the room left for a multidisciplinary assessment. The multidisciplinary 'constitutive story' of islands and insularity has yet to be written-and this collection of papers aims to contribute to such an assessment.

\section{References}

Allaby, Michael. 2020. Continentality. Oxford dictionary of geology \& earth sciences. Oxford: OUP.

Athanassiou, Phebou, and Stéphanie Laulhé Shaelou. 2014. EU Accession from Within? An Introduction. Yearbook of European Law 33: 335.

Beckles, Hilary McD. 1999. The 'Hub of Empire': The Caribbean and Britain in the Seventeenth Century. In The Oxford History of the British Empire. Volume I: The Origins of the Empire, ed. Nicholas Canny. Oxford: OUP.

Berthet, Dominique. 2020. Création et insularité. Paris: L'Harmattan.

Bocco, Gerardo. 2016. Remoteness and remote places. A geographic perspective. Geoforum 77: 178.

Bottomley, Anne. 2020. Between islands: colonial legacies and cultural imaginaries. Pólemos 14: 237.

Boumpa, Anna and Paralikas, Apostolos. 2021. The Greek Archipelago: A unique representative casestudy of differential legal status and of double insularity. Liverpool Law Review 42.

Bromby, Michael. 2021. The Cayman Islands: Paradoxes of Insularity in the Caribbean and other British Overseas Territories. Liverpool Law Review 42.

Dasgupta, Susmita, et al. 2009. The impact of sea level rise on developing countries: A comparative analysis. Climate Change 93: 379.

Eco, Umberto. 2013. Storia delle terre e dei luoghi leggendari. Milan: Bompiani.

Faccio, Sondra. 2021. "Human habitation or economic life of their own." The definition of an island between history, technology and the law. Liverpool Law Review 42.

Ferraris, Luchino and Frinzi, Gianluca. 2021. Rural development and the "POSEI" regime for European islands: between remoteness, subsidiarity and the "Delivery Model". Liverpool Law Review 42.

Fichter, James. 2008. The British empire and the American Atlantic on Tristan da Cunha, 1811-16. The Journal of Imperial and Commonwealth History 36: 567.

Gaynor, Jennifer L. 2020. Liquid territory, shifting lands property, sovereignty, and space in Southeast Asia's tristate maritime boundary zone. In Blue legalities. The life and laws of the sea, ed. Irus Braverman et al. Durham and London: Duke UP.

Hendry, Ian, and Susan Dickson. 2018. British Overseas Territories Law. Oxford and Portland: Hart.

Hugues, Heather. 2007. Aesthetics of common law-domestic and international implications. Louisiana Law Review 67: 690. 
Johnson, Elizabeth R., and Irus Braverman. (eds.). 2020. Blue legalities. Governing more-than-human oceans. In Blue legalities. The life \& laws of the sea, ed. Elizabeth R. Johnson and Irus Braverman. Durham and London: Duke UP.

Jones, Colin. 2021. The Island that ate the constitution. Liverpool Law Review 42.

Kochenov, Dimitry (ed.). 2011. EU law of the overseas: outermost regions, associated overseas countries and territories, territories Sui Generis. Alphen aan den Rijn: Kluwer Law International.

Le Monde. 2019. Géopolitiques des îles en 40 cartes, Le Monde hors série, juillet-août 2019

Leal-Arcas, Rafael. 2013. Climate change and international trade. Cheltenham and Northampton, MA: Edward Elgar.

Lovegrove, Roger. 2012. Islands beyond the horizon. The life of twenty of the world's most remote places. Oxford: OUP.

Mann, Geoff, and Joel Wainwright. 2018. Climate leviathan: A political theory of our planetary future. London and New York: Verso.

McMahon, Elizabeth. 2016. Islands, Identity and the Literary Imagination. London: Anthem Press.

Mentz, Steve. 2015. Shipwreck modernity: Ecologies of globalization, 1550-1719. Minneapolis, MN: University of Minnesota Press.

Monateri, Pier Giuseppe. 2018. Dominus mundi. Political sublime and the world Order. Oxford: Hart.

Moore, Margaret. 2015. A political theory of territory. Oxford: OUP.

Mountz, Alison. 2015. Political geography II. Islands and archipelagos. Progress in Human Geography 39: 636 .

Nicolini, Matteo, and Thomas Perrin. 2020. Islands and insularity: Between law, geography, and fiction. Pólemos 14: 209.

Perrot, Danielle. 2021. Insularity and law: diversity and changeability of Islands' statuses. The example of French outermost regions in French and EU law systems. Liverpool Law Review 42.

Pugh, Jonathan. 2018. Relationality and island studies in the Anthropocene. Island Studies Journal 13: 93.

Chandler, David, and Jonathan Pugh. 2020. Islands of relationality and resilience: The shifting stakes of the Anthropocene. Area 52: 65-72.

Roberts-Wray, Kenneth. 1966. Commonwealth and colonial law. London: Stevens.

Royle, Stephen A. 2011. A geography of Islands: Small Island insularity. Oxon-New York: Routledge.

Schalansky, Judith. 2010. Atlas of remote Islands: Fifty Islands I have never set foot on and never will. London: Penguin.

Smith, Barry. 2017. The Island in imagination and experience. Salford: Saraband.

Thomson, James. 1802. Britannia. In: The Works of Mr. James Thomson: With His Last Corrections and Improvements, Vol. 2. London: Printed for R. Baldwin.

Tolias, George. 2007. Isolarii, Fifteenth to Seventeenth Century. In Cartography in the European renaissance, vol. 8, ed. D. Woodward. Chicago: University of Chicago Press.

Waters Bennett, Josephine. 1956. Britain among the fortunate isles. Studies in Philology 53: 114.

Publisher's Note Springer Nature remains neutral with regard to jurisdictional claims in published maps and institutional affiliations.

\section{Affiliations}

\section{Matteo Nicolini ${ }^{1,2,3,4}$ (D) Thomas Perrin ${ }^{5}$ (iD}

Thomas Perrin

thomas.perrin@univ-lille.fr

1 Law Department, Verona University, Via Carlo Montanari 9, 37122 Verona, Italy

2 Newcastle Law School, Newcastle University, 21-24 Windsor Terrace, Newcastle upon Tyne NE1 7RU, UK

3 Centre for the Study of Law in Theory and Practice (LTAP), Liverpool John Moores University, Liverpool, UK 
4 Institute of Comparative Federalism, Eurac Research, Bolzano, Italy

5 Regional Planning and Urbanism, Research Centre Univ. Lille ULR 4477, TVES - Territoires Villes Environnement \& Société, University of Lille, 59000 Lille, France 